\title{
Termite Resistance of Impregnated Jabon Wood (Anthocephalus Cadamba Miq.) with Combined Impregnant Agents ${ }^{1}$
}

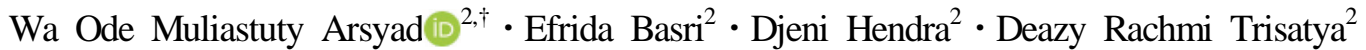

\begin{abstract}
Jabon (Anthocephalus cadamba Miq.) is a fast-growing species that exhibits a lower natural resistance than that exhibited by the timber sourced from natural forests. Jabon's resistance to termite attack can be improved by impregnating its wood structure with poisonous organic materials. This study examined jabon's resistance to termite attack when impregnated with wood vinegar and an animal adhesive. The wood specimens were impregnated using sengon wood vinegar and an animal adhesive (8\% and 10\%, respectively) using a vacuum pressure machine. The specimens were tested for their resistance to subterranean and dry-wood termites according to Indonesian National Standard (SNI 7207-2014). The results denoted that jabon impregnated with wood vinegar and an animal adhesive concentration of at least $8 \%$ with the addition of $4 \%$ borate was effective to resist termite attacks. The impregnated jabon exhibited a lower weight loss and higher termite mortality when compared with those exhibited by the control specimens. Thus, the resistance class improved from class IV to class I.
\end{abstract}

Keywords: impregnation, jabon, termite, wood resistance, wood vinegar

\section{INTRODUCTION}

Since 2000 fast growing plantations have supplied at least $60 \%$ of timber plantation in Indonesia (Hadi et al., 2015). Fast growing wood species has low natural resistance, particularly against termites attack. Previous study reported that economic losses from wood structure damage as a result of termites attack were almost 8.7 billion rupiahs (Nandika, 2015). Improvement of its physical quality is indispensable to increase its resistance against termites attack.

Jabon wood (Anthocephalus cadamba Miq.) is one of the potential fast growing species in Indonesia. Jabon contains more juvenile wood that has inferior physical and mechanical properties and lower natural resistance compared to mature wood (Lestari et al., 2018; Hermawan et al., 2012). Its resistance is classified as class IV-V or poor resistance (Martawijaya et al., 2005). To improve physical and mechanical properties and its resistance, impregnation of organic and inorganic compounds into wood structure by soaking or using vacuum pressure tube can be performed (Hadi et al., 2018; Hartono et al., 2016; Oh and Park, 2015). Wood vinegar as a by-product from pyrolysis process of

1 Date Received May 10, 2019, Date Accepted July 8, 2019

${ }^{2}$ Forest Products Research and Development Center, Ministry of Environment and Forestry, Jalan Gunung Batu No. 5, Bogor 16610, West Java, Indonesia

† Corresponding author: Wa Ode Muliastuty Arsyad (e-mail: waodemuliastuty@gmail.com, ORCID: 0000-0002-8135-7620) 
Wa Ode Muliastuty Arsyad • Efrida Basri - Djeni Hendra - Deazy Rachmi Trisatya

ligno-cellulose biomass can be applied as organic impregnant (Bridgwater, 2012; Lee et al., 2011; Tiilikkala et al., 2010). In 2015, sawn wood production capacity in Indonesia reached 1,939,586.19 $\mathrm{m}^{3}$, where $5.89 \%$ sourced from sengon wood (Falcataria moluccana) (Central Bureau of Statistics, 2016). Sawn wood processes generated wastes such as slabs, wood bark and sawdust that could be utilized as wood vinegar or wood distillate. Wood vinegar contains polycyclic aromatic hydrocarbon compounds. The compounds comprise numerous major components such as phenol, formaldehyde, organic acid, ketones, hydrocarbon, ester, alcohols and some heterocyclic materials (Haji, 2013; Tascioglu et al., 2012; Kim et al., 2008). Wood vinegar contains compounds that poisonous to bacteria (Lee et al., 2010), fungi (Okutucu et al., 2011; Islam et al., 2009) and termite (Oramahi and Yoshimura, 2013; Hadi et al., 2010). It could be argued that wood vinegar could be used as wood natural preservative (Verma et al., 2009). Wood vinegar from coconut husks, sugarcane (Arundo donax sp.), laban (Vitex pubescens) increased mortality of Odontotermes sp., Reticulitermes flavipe in Pinus sylvestris L. and C. curvignathus, consecutively (Oramahi et al., 2014; Temiz et al., 2013; Wititsiri, 2011).

The purpose of this study was to determine the resistance of impregnated jabon wood with various treatment combinations against subterranean and dry-wood termites.

\section{MATERIALS and METHODS}

\subsection{Study site/materials}

Five-year-old jabon from community forest in Sukabumi, West Java was tested against subterranean (Coptotermes curvignathus Holmgren) and dry-wood (Cryptotermes cynocephalus Light) termites attack. Wood vinegar was generated from slabs and wood bark of five-year-old sengon. Animal adhesive resin was composed from hides, bones, cartilage and tendons of animal. Borate was used as preservative.

\subsection{Preparation of sample test, animal adhesive and impregnant agents}

Five replications for each treatment with a dimension of $2.5 \mathrm{~cm} \times 2.5 \mathrm{~cm} \times 0.5 \mathrm{~cm}$ and $5 \mathrm{~cm} \times 2 \mathrm{~cm} \times 2 \mathrm{~cm}$ were made for subterranean and dry-wood termites test, respectively. Three kg of sengon slabs and wood barks were put in a modified condensed drum and pyrolyse (dry distillation) at $200-400^{\circ} \mathrm{C}($ Darmadji et al., 2000). Smoke was then condensed into liquid. The liquids collected in the condenser were about 1.5 litres.

Animal adhesive was in solid form. Thus, it should be distillated to soften the adhesive. The animal adhesive was mixed with $66^{\circ} \mathrm{C}$ destilled water its application to the wood (Conner, 2001). Impregnant agents used in the study were a mixture of wood vinegar and animal adhesive resin with the later concentration $8 \%$ and $10 \%$. The addition of $4 \%$ borate in the formula was aiming for contrasting the resistance of impregnated jabon with the untreated impregnated jabon.

All samples were oven dried at $63^{\circ} \mathrm{C}$ to reach $10 \%$ moisture content. Those samples were then weighed and placed in a 10-litre-vacuum-pressure tube for 30 minutes. The tube was filled with impregnant agent and vacuum at $12 \mathrm{~kg} / \mathrm{cm}^{2}$ pressure for 60 minutes. Afterwards, all samples were dried in the oven at $63^{\circ} \mathrm{C}$ to reach $10 \%$ moisture content, and weighed.

\subsection{Testing the chemical components of impregnant agents}

Samples of mixed wood vinegar and animal adhesive were analysed using Gas Chromatography Mass Spectometry (GC-MS) Shimadzu GC-MS-QP 2010S. Column and injection oven temperature was set to $280^{\circ} \mathrm{C}$ while pyrolyzer temperature was set at $300^{\circ} \mathrm{C}$ with 101.0 $\mathrm{kPa}$ in 50 minutes (Fowlis, 1995). 


\subsection{Testing the resistance of impregnated jabon to termites attack}

The Indonesian National Standard (SNI 7207-2014) was referred to test the resistance of impregnated jabon to termites attack (Indonesian National Standard Bureau, 2014). The resistance to subterranean termite attack was tested with the following procedures. Samples were put in glass containers with 200 gr of moist sand which has $7 \%$ moisture content under water holding capacity and 200 sound and active workers of subterranean termites. The containers were then placed in a dark room for four weeks. After four weeks, the samples were oven-dried.

The resistance of impregnated jabon to dry-wood termite attack was tested by placing $1.8 \mathrm{~cm}$ diameter and $3 \mathrm{~cm}$ height glass tube at the widest side of the samples. Fifty sound and active workers of dry-wood termites were put into the tube. The tube was placed in a dark room for twelve weeks. After twelve weeks, the samples were oven-dried.

At the end of the observation, weight loss and termites mortality were determined. As a control, the resistance test of impregnated jabon to termites attack with the absence of borate was also performed. As a standard, SNI 7207-2014 was applied for classifying wood resistance to subterranean and dry-wood termites attack (Indonesian National Standard Bureau, 2014).

\subsection{Data analysis}

Completely Randomized Design with single factor was performed using SPSS ver.23. There were five replications of eight combinations of impregnant agents and one control samples. Analysis of Variance was used to determine the influence of treatment to weight loss and termite mortality. Duncan's test was carried out for further analysis if the factor was significantly different (Steel and Torrie, 1995).

\section{RESULTS and DISCUSSION}

\subsection{Termite mortality}

Termite mortality is one of the parameters to assess the efficacy of preservative to increase the resistance of wood to termite attack (Ngadianto et al. 2011). The analysis of variance showed that the impregnation of wood vinegar and animal adhesive into jabon wood has significant effect on mortality rate of subterranean and dry-wood termites attack $(\mathrm{P}<0.05)$. Subterranean and dry-wood termite mortality of impregnated and control jabon was presented in Fig. 1.

As shown in Fig. 1, termite mortality in control jabon was the lowest (18.6\% for subterranean and $23.6 \%$ for dry-wood termites) compared to the impregnated jabon. Subterranean and dry-wood termite mortality in impregnated jabon with mixed animal adhesive and distilled water was around $41.4 \%-42.5 \%$ and $42.4 \%$ 45.4\%, respectively. Furthermore, the resistance of impregnated jabon with animal adhesive and wood vinegar to termite infestation was improved. The difference concentration of animal adhesive used in this research was based on the previous studies (Basri et al., 2016; Basri et al., 2015). It was shown that the $8 \%$ of animal adhesive was superior to dimension stability and density (Basri et al., 2015). However, 12\% of animal adhesive was not effective to the physical properties of impregnated jabon wood (Basri et al., 2015). It was reported that the denser particleboard was more resistant to termite attack in comparison to less denser particleboard (Indrayani et al., 2014). Therefore, $8 \%$ and $10 \%$ of animal adhesive were applied in this research to test the effective concentration on termite resistance. The mortality rate for subterranean and dry-wood termites was 62.3\%-65.8\% and 62.3\%-65.8\%, consecutively. The efficacy of wood vinegar as antitermite agent depends on its concentration and chemical composition (Oramahi et al., 2014). 


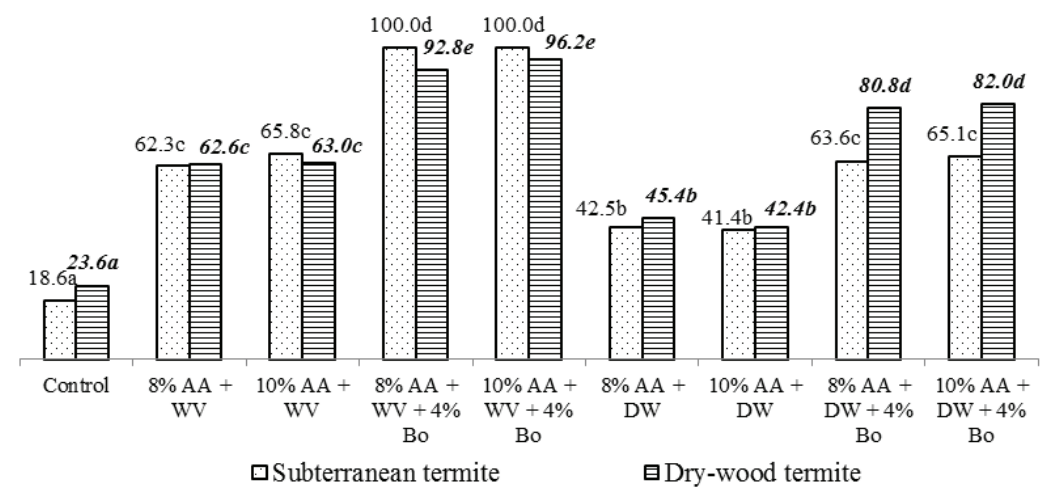

Remarks: Means followed by the same letter(s) in the same column are not significantly different at the 5\% probability level according to Duncan's test

Fig. 1. Termite mortality of impregnated and control jabon.

Termite mortality rate in impregnated jabon with mixed animal adhesive (8\% and 10\%) and wood vinegar with the addition of $4 \%$ borate was the highest compared to other treatments. Formula used in this treatment was very effective in increasing wood resistance, as the mortality rate for subterranean and dry-wood termites was $100 \%$. This is in line with earlier study which revealed that the resistance of Japanese cedar (Cryptomeria japonica) and white cedar (Melia azedarach) against termite attack was increased by preserving with mangium wood vinegar and 5\% borate (Hadi et al., 2010). This study, however, used lessen borate concentration yet adequate to enhance toxicity of chemical compounds in the wood vinegar. The mixture of animal adhesive, wood vinegar and borate resulted in more resistant wood compared to the mixture formula of animal adhesive and wood vinegar. Borate is a natrium active compound that tends to absorp fluid. Wood vinegar compounds will bond with wood organic compounds which will fill lumen and cell wall (Suryono, 2009). The addition of $4 \%$ borate in mixed animal adhesive and distilled water formula enabled the impregnated jabon to reach $63.6 \%-65.1 \%$ and $80.8 \%$ $82.0 \%$ mortality rate of the subterranean and dry-wood termites (Fig. 1). Nevertheless, mortality rate which is under $90 \%$ was disfavour since it implies that the wood does not durable to infestation. To resist from termite attack it required minimum concentration of $7.5 \%$ boric acid-water solution and to reach $98 \%$ of subterranean termite mortality rate, $10 \%$ boric acid-water solution was added (Darmono et al., 2013).

Analysis of chemical components revealed that sengon wood vinegar was dominated by phenol 2,6dimethoxy, 2-propenoic acid and 3-phenyl compounds (Table 1). Those chemical compounds, however, less toxic to subterranean and dry-wood termites attack as indicated by low mortality rate $(<70 \%)$ of subterranean and dry-wood termite (Fig. 1). It could be argued that phenolic and carboxylic acid compounds were bonded with other chemical compounds, such as dimethyl, hydroxyl, phenyl propan and acetic acid, thus lessen its toxicity to termite infestation (Table 1).

The addition of $4 \%$ borate into the formula augmented termite mortality to more than $90 \%$. Further, it reached $100 \%$ of mortality rate of dry-wood termite. It is assumed that the adding of borate in wood vinegar could enhance toxic in its chemical compounds.

Borax $\left(\mathrm{Na}_{2} \mathrm{~B}_{4} \mathrm{O}_{7} \cdot 10 \mathrm{H}_{2} \mathrm{O}\right)$ is a mixed of high concentrated sodium salt with $\mathrm{pH} 9.5$ (alkaline) and could be used as wood preservative (Suheryanto, 2012). The 
Table 1. Chemical components concentration of impregnant agents

\begin{tabular}{|c|c|c|c|c|}
\hline \multirow[b]{2}{*}{ No } & \multirow[b]{2}{*}{ Chemical components } & \multicolumn{3}{|c|}{ Impregnant agents concentration (\%) } \\
\hline & & WV & $\begin{array}{c}8 \% \text { AA + DW + } \\
4 \% \text { Bo }\end{array}$ & $\begin{array}{c}8 \% \mathrm{AA}+\mathrm{WV}+4 \% \\
\text { Bo }\end{array}$ \\
\hline \multirow[t]{7}{*}{1} & Phenolic groups & & & \\
\hline & - Phenol, 2,6-dimethoxy & 20.84 & - & 23.45 \\
\hline & - Phenol, 2,5-dimethyl & 2.15 & & 4.16 \\
\hline & - 2-Hydroxyphenol & 8.25 & - & 10.34 \\
\hline & - Phenol, 2-methoxy-4-methyl & 7.22 & - & 9.15 \\
\hline & - Phenol, 2-ethyl & 1.60 & - & 3,16 \\
\hline & - Phenol, 4-(2-aminopropyl) & 0.86 & - & 2.22 \\
\hline \multirow[t]{7}{*}{2} & Carboxylic groups & & & \\
\hline & - 2-Propenoic acid, 3-phenyl & 19.72 & 17.5 & 21.74 \\
\hline & - Benzenepropanoic acid, methyl ester & 7.79 & 5.25 & 9.15 \\
\hline & - Hexadecanoic acid, methyl ester & 4.78 & 3.00 & 6.91 \\
\hline & - Octadecanoic acid, methyl ester & 3.25 & 2.43 & 0.34 \\
\hline & - 3-amino-2-benzyl-butanoic acid & 1.34 & 0.62 & 2.49 \\
\hline & - Pterine-6-carboxylic acid & 1.36 & 0.46 & 2.04 \\
\hline
\end{tabular}

Remarks: $\mathrm{WV}=$ wood vinegar; $\mathrm{AA}=$ animal adhesive; $\mathrm{DW}=$ distilled water; Bo=borate.

sodium salt is a soft crystal which consists of boron compound (Sumaryanto et al., 2013) and has toxic insecticidal activity to protozoa (Ewart and Cookson, 2014). Termites secrete cellulose with the aid of digestive enzymes that are produced by protozoa in their gut (Hu et al., 2011; Poinar, 2009). The application of optimal concentration of borate in preserved wood would kill protozoa in their gut. Thus, cellulose could not be digested, termites would be starving, stress and cannibalism would be likely to occur (Nandika, 2015; Hu et al., 2011; Poinar, 2009). Cannibalism is an adaptive behaviour to survive in the colony (Haifig et al., 2017).

\subsection{Resistance to termite attack}

The average of impregnated jabon resistance to termite attack is presented in Table 2. Based on analysis of variance, treatments applied in the study had significant effect to mass loss $(\mathrm{P}<0.05)$.

Mass losses of the untreated (control) jabon were
$17.73 \%$ for subterranean and $20.40 \%$ dry-wood termites. Compared to other treatments, these proportions were the highest. Due to its low resistance to subterranean and dry-wood, control jabon was categorized as class IV. Similarly, impregnated jabon with mixed animal adhesive and distilled water fell into class IV as it mass loss were $13.40 \%$ and $12.21 \%$ for subterranean termite; $13.77 \%$ and $12.94 \%$ for dry-wood termite, with $8 \%$ and $10 \%$ animal adhesive concentration, respectively. Animal adhesive is nontoxic to wood destroying organisms. Animal adhesive is a protein colloid adhesive which is derived from hides, bones, tendons and cartilage. This adhesive dissolves in hot water and would harden when it is cooled (Ebnesajjad, 2010). Animal adhesive in impregnant formula plays an important role as a bonding agent or reinforcing wood structure (Basri et al., 2016).

Wood vinegar contained carboxylic and phenolic compounds that poisonous to termite, while borate only contained carboxylic compound (Table 1). However, those chemical compounds should be bonded together 
Table 2. Jabon resistance against termites attack

\begin{tabular}{|c|c|c|c|c|}
\hline \multirow{2}{*}{ Treatment } & \multicolumn{2}{|c|}{$\begin{array}{l}\text { Subterranean termite } \\
\text { (C. curvignathus Holmgren) }\end{array}$} & \multicolumn{2}{|c|}{$\begin{array}{c}\text { Dry-wood termite } \\
\text { (C. cynocephalus Light) }\end{array}$} \\
\hline & $\begin{array}{c}\text { Mass loss } \\
(\%)\end{array}$ & $\begin{array}{l}\text { Resistance } \\
\text { class }\end{array}$ & $\begin{array}{c}\text { Mass loss } \\
(\%)\end{array}$ & $\begin{array}{c}\text { Resistance } \\
\text { class }\end{array}$ \\
\hline Control & $17.73 \pm 2.49 \mathrm{e}$ & IV & $20.40 \pm 0.66 \mathrm{e}$ & IV \\
\hline $8 \%$ AA+WV & $10.72 \pm 1.48 \mathrm{c}$ & III & $7.68 \pm 1.74 \mathrm{c}$ & III \\
\hline $10 \% \mathrm{AA}+\mathrm{WV}$ & $10.57 \pm 0.42 \mathrm{c}$ & III & $6.14 \pm 1.49 \mathrm{c}$ & III \\
\hline $8 \% \mathrm{AA}+\mathrm{WV}+4 \%$ Bo & $3.33 \pm 0.79$ a & I & $1.92 \pm 1.18 \mathrm{a}$ & I \\
\hline $10 \% \mathrm{AA}+\mathrm{WV}+4 \%$ Bо & $2.87 \pm 1.42 \mathrm{a}$ & I & $1.57 \pm 0.94 \mathrm{a}$ & I \\
\hline $8 \% \mathrm{AA}+\mathrm{DW}$ & $13.40 \pm 0.70 \mathrm{~d}$ & IV & $13.77 \pm 1.81 \mathrm{~d}$ & IV \\
\hline $10 \% \mathrm{AA}+\mathrm{DW}$ & $12.21 \pm 0.76 \mathrm{~cd}$ & IV & $12.94 \pm 1.47 \mathrm{~d}$ & IV \\
\hline $8 \%$ AA+DW+4\% Bo & $8.87 \pm 0.96 b$ & III & $4.23 \pm 0.67 b$ & II \\
\hline $10 \% \mathrm{AA}+\mathrm{DW}+4 \%$ Bo & $8.79 \pm 0.87 b$ & III & $3.87 \pm 0.44 b$ & II \\
\hline
\end{tabular}

Remarks: WV=wood vinegar; $\mathrm{AA}=$ animal adhesive; $\mathrm{DW}=$ distilled water; $\mathrm{Bo}=$ =borate. Means followed by the same letter(s) in the same column are not significantly different at the $5 \%$ probability level according to Duncan's test

to impose high toxic to termite. In this study, carboxylic and phenolic compounds were bonded with other chemical compounds, as stated earlier.

The addition of $4 \%$ borate in wood vinegar was significantly increase jabon resistance to subterranean and dry-wood termite from class IV to class I. This could be explain as the mixture of borate and wood vinegar formed more reactive chemical reaction and increase its toxic to subterranean and dry-wood termites. Further analysis should be performed to develop more robust carboxylic and phenolic compounds-based formula which durable to termite attack in contrast to the efficacy of borate.

\section{CONCLUSION}

Impregnated jabon with at least $8 \%$ animal adhesive and wood vinegar raised its resistance to termite infestation. However, since the mortality rate was still below $70 \%$ such treatments were still inadequate to struggle from subterranean and dry-wood termites attack. Resistance class of impregnated jabon with animal adhesive and wood vinegar against subterranean and dry-wood termites attack slightly increased from class IV to class III and from class IV to class II, consecutively.

The addition of $4 \%$ borate in mixed animal adhesive and wood vinegar was efficient to resist from termites attack. It seems borate plays important factor for this matter. This treatment was made the lowest mass loss of impregnated jabon and reached more than $90 \%$ of mortality rate. Thus, the resistance class of jabon wood improved from class IV to class I.

\section{REFERENCES}

Basri, E., Balfas, J., Hendra, D., Yuniarti, K., Santoso, A. 2015. Formulation of Impregnation and Finishing Materials for Wood. Research Report. Forest Products Research and Development Center. Bogor.

Basri, E., Balfas, J., Hendra, D., Yuniarti, K., Santoso, A. 2016. Formulation of impregnation and finishing materials for wood. Research Report. Forest Products Research and Development Center. Bogor.

Bridgwater, A.V. 2012. Review of fast pyrolysis of biomass and product upgrading. Biomass and Bioenergy 38: 68-94.

Central Bureau of Statistics. 2016. Forestry Production 
Statistics 2015. Jakarta.

Conner, A.H. 2001. Wood: Adhesives. Encyclopedia of materials: Science and technology. Amsterdam, New York: Elsevier Science, Ltd.

Darmadji, P., Oramahi, H.A., Haryadi, Armunanto, R. 2000. Optimasi produksi dan sifat fungsional asap cair kayu karet. Agritech 20(3): 147-155.

Darmono, Atun, S., Prasetyo, S. 2013. Pemanfaatan campuran boraks dan asam borat sebagai bahan pengawetan kayu terhadap serangan rayap. Inotek1 17(1): 82-99.

Ebnesajjad, S. 2010. Handbook of Adhesives and Surface Preparation. Handbook of Adhesives and Surface Preparation. Elsevier.

Ewart, D., Cookson, L.J. 2014. Termites and Timber. In Deterioration and Protection of Sustainable Biomaterials. American Chemical Society, pp. 159-181.

Fowlis, I.A. 1995. Gas Chromatography Analytical Chemistry by Open Learning (Second Ed). John Wiley \& Sons Ltd. West Sussex.

Hadi, Y.S., Massijaya, M.Y., Zaini, L.H., Abdillah, I.B., Arsyad, W.O.M. 2018. Resistance of methyl methacrylate-impregnated wood to subterranean termite attack. Journal of the Korean Wood Science and Technology 46(6): 748-755.

Hadi, Y.S., Nurhayati, T., Jasni, Yamamoto, H., Kamiya, N. 2010. Smoked wood resistance against termite. Journal of Tropical Forest Science 22(2): 127-132.

Hadi, Y.S., Rahayu, I. S., Danu, S. 2015. Termite resistance of jabon wood impregnated with methyl methacrylate. Journal of Tropical Forest Science 27(1): 25-29.

Haifig, I., Lima, J.T., Janei, V., Costa-Leonardo, A.M. 2017. Effects of group size and starvation on survival of the Asian subterranean termite Coptotermes gestroi (Isoptera: Rhinotermitidae). Austral Entomology.

Haji, A.G. 2013. Komponen kimia asap cair hasil pirolisis limbah padat kelapa sawit. Jurnal Rekayasa Kimia dan Lingkungan 9(3): 109-116.

Hartono, R., Hidayat, W., Wahyudi, I., Febrianto, F.,
Dwianto, W., Jang, J.H., Kim, N.H. 2016. Effect of phenol formaldehyde impregnation on the physical and mechanical properties of soft-inner part of oil palm trunk. Journal of the Korean Wood Science and Technology 44(6): 842-851.

Hermawan, D., Hadi, Y.S., Fajriani, E., Massijaya, M.Y., Hadjib, N. 2012. Resistance of particleboards made from fast-growing wood species to subterranean termite attack. Insects 3(2): 532-537.

Hu, X.P., Song, D., Gao, X. 2011. Biological changes in the Eastern subterranean termite, Reticulitermes flavipes (Isoptera, Rhinotermitidae) and its protozoa profile following starvation. Insectes Sociaux 58(1): 39-45.

Indonesian National Standard Bureau. 2014. Wood resistance test to wood destroying organism (SNI 7207-2014). Jakarta.

Indrayani, Y., Hardiansyah, G., Pari, G. 2014. Termite resistance of three layer particleboard Shorea leprosula Miq. from natural and plantation forest. In: Hartono et al. (eds.), Medan, Indonesia, Proc. of the 6th International Symposium of Indonesian Wood Research Society, pp. 130.

Islam, M.M., Shams, M.I., Ilias, G.N.M., Hannan, M.O. 2009. Protective antifungal effect of neem (Azadirachta indica) extracts on mango (Mangifera indica) and rain tree (Albizia saman) wood. International Biodeterioration and Biodegradation 63(2): 241-243.

Kim, D.H., Seo, H.E., Lee, S.C., Lee, K.Y. 2008. Effects of wood vinegar mixted with insecticides on the mortalities of Nilaparvata lugens and Laodelphax striatellus (homoptera: Delphacidae). Animal Cells and Systems12(1): 47-52.

Lee, S., Ahn, B., Cho, S. 2010. Antimicrobial activities of wood vinegar and application as natural fungicides and food preservatives. Journal of the Korean Wood Science and Technology 38(4): 341-348.

Lee, S.H., H'ng, P.S., Chow, M.J., Sajap, A.S., Tey, B.T., Salmiah, U., Sun, Y.L. 2011. Effectiveness of 
pyroligneous acids from vapour released in charcoal industry against biodegradable agent under laboratory condition. Journal of Applied Sciences 11(24): 3848-3853.

Lestari, A.S.R.D., Hadi, Y.S., Hermawan, D., Santoso, A. 2018. Physical and mechanical properties of glued laminated lumber of pine (Pinus merkusii) and jabon (Anthocephalus cadamba). Journal of the Korean Wood Science and Technology 46(2): 143-148.

Martawijaya, A., Kartasujana, I., Mandang, Y., Prawira, S.A., Kadir, K. 2005. Atlas Kayu Indonesia Jilid II. Pusat Penelitian dan Pengembangan Hasil Hutan. Bogor.

Nandika, D. 2015. Satu Abad Perang Melawan Rayap. Jakarta.

Ngadianto, A., Ragil, W., Lukmandaru, G. 2011. Ketahanan papan partikel limbah kayu mahoni dan sengon dengan perlakuan pengawetan asap cair terhadap serangan rayap kayu kering Cryptotermes. Biokomposit XV: 213-219.

Oh, S.W., Park, H.J. 2015. Vacuum pressure treatment of water-soluble melamine resin impregnation for improvement of dimensional stability on softwoods. Journal of the Korean Wood Science and Technology 43(3): 327-333.

Okutucu, C., Duman, G., Ucar, S., Yasa, I., Yanik, J. 2011. Production of fungicidal oil and activated carbon from pistachio shell. Journal of Analytical and Applied Pyrolysis 91(1): 140-146.

Oramahi, H.A., Purwati, Zainal, S., Iskandar, Idham, Diba, F., Wahdina. 2014. Efikasi asap cair dari kayu laban (Vitex pubescens) terhadap rayap Coptotermes curvignatus. Jurnal Hama dan Penyakit Tumbuhan Tropika 14(1): 71-79.

Oramahi, H.A., Yoshimura, T. 2013. Antifungal and antitermitic activities of wood vinegar from Vitex pubescens Vahl. Journal of Wood Science 59(4): 344-350.

Poinar, G.O. 2009. Description of an early Cretaceous termite (Isoptera: Kalotermitidae) and its associated intestinal protozoa, with comments on their coevolution. Parasites and Vectors 2(1): 1-17.

Steel, R.G., Torrie, J.H. 1995. Prinsip dan prosedur statistika: Suatu pendekatan biometrik (2nd ed.). Gramedia Pustaka Utama. Jakarta.

Suheryanto, D. 2012. Pengaruh konsentrasi borak terhadap keawetan kayu karet. Surabaya.

Sumaryanto, A., Sucipto, A.H., Lukmandaru, G. 2013. Pengawetan kayu gubal jati secara rendaman dingin dengan pengawet boron untuk mencegah serangan rayap kayu kering (Cryptotermes cynocephalus Light.). Jurnal Ilmu Kehutanan VII(2): 93-107.

Suryono, A. 2009. The liquid smoke of coconut shell as rubber wood preservative from the attack of subterranean termite (Coptotermes curvignathus Holmgren). Master. Thesis. Institut Pertanian Bogor. Indonesia.

Tascioglu, C., Yalcin, M., de Troya, T., Sivrikaya, H. 2012. Termiticidal properties of some wood and bark extracts used as wood preservatives. BioResources 7(3): 2960-2969.

Temiz, A., Akbas, S., Panov, D., Terziev, N., Alma, M.H. 2013. Chemical composition and efficiency of bio-oil obtained from giant cane (Arundo donax L.) as a wood preservative. BioResources 8(2): 2084-2098.

Tiilikkala, K., Fagernäs, L., Tiilikkala, J. 2010. History and use of wood pyrolysis liquids as biocide and plant protection product. The Open Agriculture Journal 4: 111-118.

Verma, M., Sharma, S., Prasad, R. 2009. Biological alternatives for termite control: A review. International Biodeterioration and Biodegradation 63(8): 959-972.

Wititsiri, S. 2011. Production of wood vinegars from coconut shells and additional materials for control of termite workers, Odontotermes sp. and striped mealy bugs, Ferrisia virgata. Songklanakarin Journal of Science and Technology 33(3): 349-354. 